
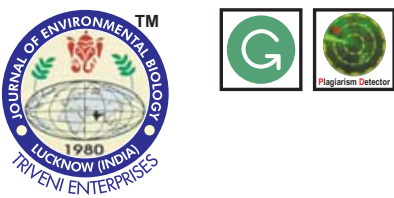

DOI: https://doi.org/10.22438/jeb/38/3/MS-245

\section{Journal of Environmental Biology}

SSN: 0254-8704 (Print)

ISSN: 2394-0379 (Online)

CODEN: JEBIDP

\title{
Understanding haematopoiesis as survival strategy in two characteristic habitat specialist fishes inhabiting a hill stream environment
}

Authors Info

A. Chaudhuri, K. Gangopadhyay and S. Homechaudhuri*

Department of Zoology, Aquatic Bioresource Research Laboratory, University of Calcutta,

Kolkata-700 019, India

${ }^{*}$ Corresponding Author Email : sumithomec@yahoo.com

Key words

Garra gotyla gotyla

Garra annandalei,

Head kidney,

Haematopoiesis,

Survival strategy

Publication Info

Paper received : 09.01.2016

Revised received: 13.06 .2016

Accepted: 06.11 .2016

\section{Abstract}

Aim: The torrential hill streams of eastern Himalayan region represent a unique lotic water ecosystem. The fish population inhabiting this region are designated as habitat specialists. Being good indicator of different environmental factors, haematopoiesis can be considered as an important component in survival strategy of such characteristic fish. So, the aim of the present study was to perform quantitative and qualitative evaluation of developing blood cells in the head kidney of two such habitat specialist fish species of River Murti- Garra gotyla gotyla and Garra annandalei.

Methodology: Garra gotyla gotyla and Garra annandalei were collected from three different sites of river Murti selected along decreasing altitudinal gradient and different habitat type. Tissue imprint technique and haematopoietic efficiency determination method were employed for qualitative and quantitative analysis of haematopoietic cells. Cell cycle phase distribution of nuclear DNA of head kidney cells were determined by flow cytometry.

Results: Eleven types of hematopoietic precursors and mature cells in erythroid and lymphoid lineage at different developmental stages were identified and documented through cytological description and morphometry in head kidneys of both the species. The erythroid lineage was dominant over all other lineages with relatively less storage forms and more young and mature erythrocyte population which was about $55.73 \%$ and $47.74 \%$ of the whole haematopoietic components studied in Garra gotyla gotyla and Garra annandalei, respectively. The flow cytometry analysis of the head kidney cells of both the species according to their Forward scatter (size) and Side scatter (granularity) properties revealed two distinct populations corresponding to small agranular and large granular cells. The percentage distribution of such cells by flow cytometry corroborated with the observation under light microscopy. Cell cycle analysis and erythropoietic efficiency of head kidney also revealed significantly high maturation rate of developing blood cells in Garra gotyla gotyla than Garra annandalei.

Interpretation: The differential pattern of erythropoiesis might indicate its functional significance reflecting differences in the survival strategies and habitat selection of Garra gotyla gotyla and Garra annandalei.

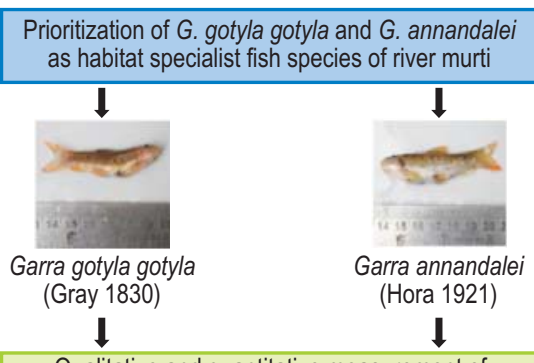

Qualitative and quantitative measurement of haematopoietic cell lineage from head kidney of both the species adapted to different habitat conditions

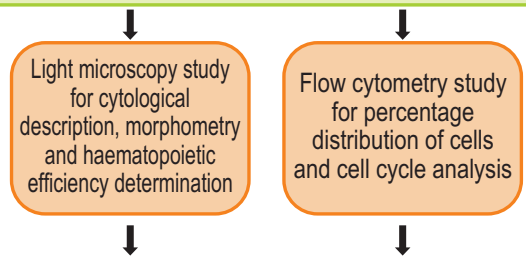

-Erythroid lineage found dominant among 11 types of haematopoietic precursor and mature cells -Relatively less storage form and more young and mature erythrocyte population in erythroid lineage - High rate of cell turn over in G. gotyla gotyla than G. annandalei

\section{$\downarrow$}

Differential pattern of erythropoiesis correlated with different survival strategies 


\section{Introduction}

India, one of the megadiversity hot spots possesses substantial freshwater biodiversity constituting 756 species and the Himalayan region itself harbouring around 500 fish species (Abell et al., 2008). The spring-fed torrential hill streams of the eastern Himalayan region represent a unique lotic water ecosystem characterized by rocky and gravely bottoms, high transparency, low temperature, high oxygen level and water velocity (Acharjee and Barat, 2011; 2014). The fish population in this region survives only in clear stream water with adequate water current, low temperature and with rocky substrate and thus, designated as habitat specialists (Chakrabarty and Homechaudhuri, 2013). Different studies have documented the diversity of ichthyofauna in North Bengal (Bahuguna and Badoni, 2002; Acharjee and Barat, 2013) but almost no work has been done on haematopoiesis as an adaptive strategy of such characteristic fish in this region.

In fish, the haematopoietic stem cells are only produced at definitive stage and the adult location for production of all such cell types is the developing kidney marrow or head kidney (Fijan 2002a, 2002b; Davidson and Zon, 2004; Chen and Zon, 2009; Kulkeaw and Sugiyama, 2012). The pronephros or head kidney is not only a basic organ forming the blood elements, but also a reservoir of blood cells (Kondera, 2011).

Despite several reports on histology and ultrastructure of head kidney tissue (Gupta and Kumar, 2006; Abdel-Aziz et al., 2010; Santos et al., 2011; Kondera, 2014), quantitative data on the cellular composition of haematopoietic organs in teleosts are scarce and incomplete (Fijan, 2002a, 2002b; Kondera, 2014).

Inspite of the circulating blood cells being good indicators of environmental impacts, data on the effects of environmental factors on haematopoietic tissue, which are particularly sensitive due to its high rate of cell turnover, is meagre (Kondera 2011). In this context, Garra gotyla gotyla and Garra annandalei have been selected as habitat specialist fish species. The present study was thus designed to examine the potency of haematopoiesis as one of the survival strategies of these two species, as well as to generate baseline information on fish inhabiting hill stream conditions.

\section{Materials and Methods}

Study area and fish sampling : Fish sampling was carried out at River Murti which rises from the Mo forest (near the Neora Valley National Park) in Darjeeling Himalayas (2211 m asl) flowing its way along the Dooars Region before it meets the Jaldhaka River (102 $\mathrm{m}$ asl). The study sites were selected at different ecological zones based on elevation gradient and habitat type namely Rocky Island (MR-I), Samsing (MR-II) and North Dhupjhora (MRIII). The river Murti at Rocky Island flows through a hilly region at an altitude of $516 \mathrm{~m}$ asl and reaches the plains at Samsing (402 m asl), $3 \mathrm{~km}$ down from Rocky Island. The third site is located at North Dhupjhora (137 m asl), $26 \mathrm{~km}$ down from Samsing and is named after the River Murti. Monthly sampling was carried out for 2 years (from July 2013 to June 2015) in the river at these three sampling sites (for a stretch of $1 \mathrm{~km}$ at each site) using cast net (having mesh size of $1 \mathrm{~cm}$ and covering an area of about $4.5 \mathrm{~m}^{2}$ ) and gill net $(20 \mathrm{~m}$ in length with $3 \mathrm{~cm}$ spacing between adjacent knots). Garra gotyla gotyla (Gray 1830) and Garra annandalei (Hora 1921) with a body mass of $7.1 \pm 2.5 \mathrm{~g}$ and $6.3 \pm 1.7 \mathrm{~g}$ and length of $13.5 \pm 2.3 \mathrm{~cm}$ and $9.2 \pm 1.6 \mathrm{~cm}$, respectively, were obtained by sampling and identified to the lowest taxonomic level using Talwar and Jhingran (1991) and Day (1889).

Quantitative and Qualitative analysis: Twelve fish from both the species were sacrificed for each experiment by cutting the spinal cord quickly with sharp scissors. For haematopoietic study, the imprint or impression technique was employed following Mahajan and Dheer (1980). A small piece from the head kidney (pronephric kidney) was carefully dissected out and impression or imprint of the tissue was made on clean glass slides. The preparation was air dried and stained with Graham Knoll's benzidine method (Forteza Bover, 1964), followed by counter staining with Giemsa (Mahajan and Dheer, 1979). The cells from haematopoietic organs were measured by ocular micrometer (LM magnification $10 \times 100$ ) in light microscope (Leica DM1000). Area of the circular cells was calculated by $\pi r^{2}$, where $r$ is the radius of the cell, and that of the elliptical cells by mab, where $a$ is half of major axis and $b$ is half of minor axis. Means, standard deviations (SD) of the means, standard errors (SE) of the means etc. from whole range of data were calculated by Descriptive Statistics tool of Microsoft Excel 2007. t-test was carried out using SPSS Statistics version 17.0. The differences were taken to be significant at $p<0.05$. Evaluation of haematopoietic efficiency of selected fish species was done following the method described by Homechaudhuri and Jha (2001).

Flow cytometric analysis: For determining cell cycle phase distribution of nuclear DNA, head kidney cells were fixed with $3 \%$ p-formaldehyde, permeabilized with $0.5 \%$ Triton $x-100$ and nuclear DNA was labelled with propidium iodide (PI), with a concentration of $125 \mu \mathrm{gml}^{-1}$ after RNase treatment. Cell cycle phase distribution of nuclear DNA was determined by FACS calibur (Becton Dickinson) using BD Accuri C6 software. Total 10,000 events were acquired for analysis. Histogram analysis of DNA content (X-axis, Pl-fluorescence) versus counts (Y-axis) was displayed (Loken, 1990).

\section{Results and Discussion}

The species Garra gotyla gotyla and Garra annandalei are inhabitant of torrential hill stream with high water current, and dependent on high turnover rate of haematopoietic cells for survival in such system. A small mass of pronephric kidney indicated its role as the main haematopoietic tissue in both fish. 

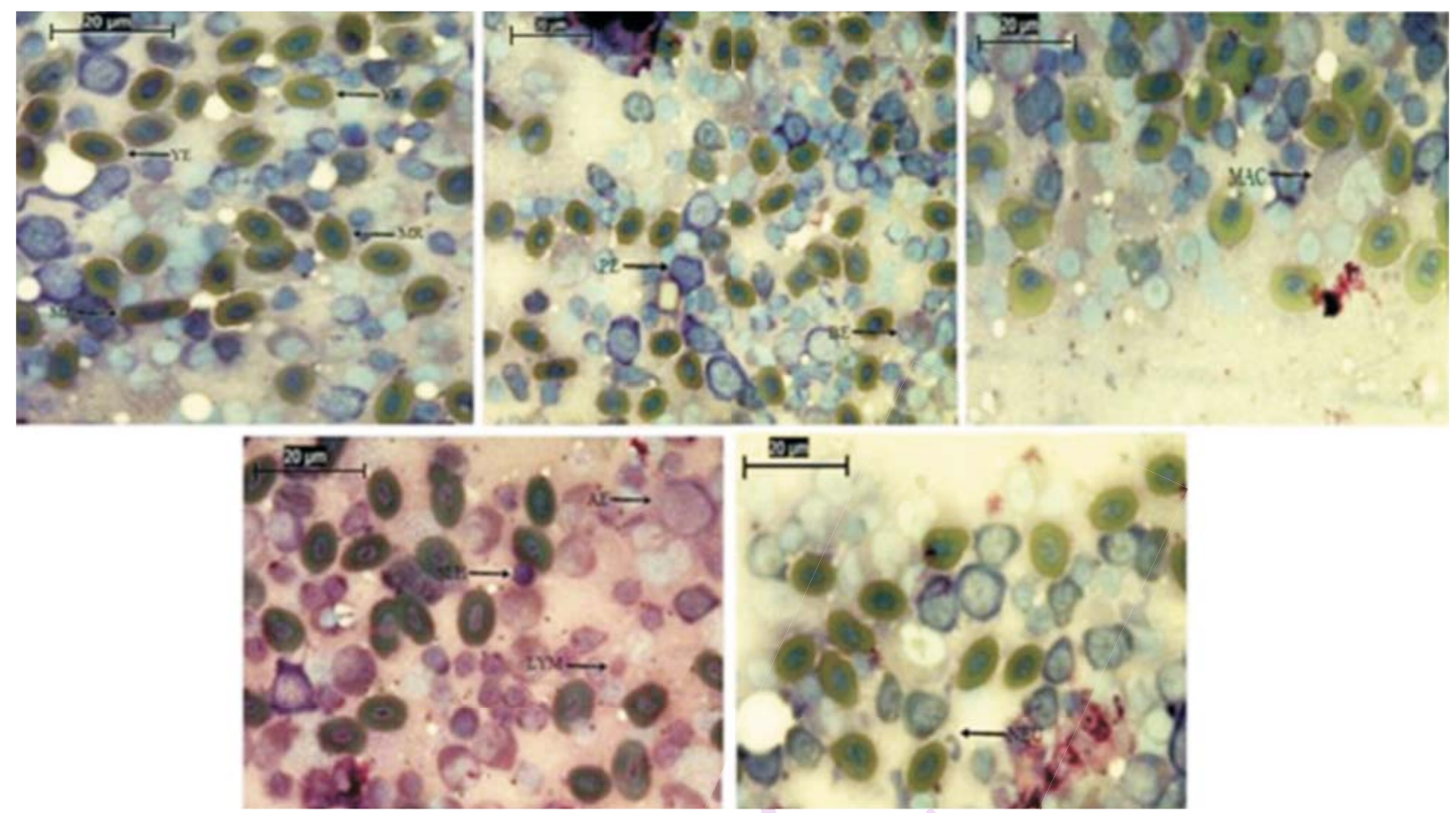

Fig. 1 : An imprint from the head kidney of G. gotyla gotyla showing Small Lymphoid Haematoblast (SLH), Basophilic Erythroblast (BE), Polychromatophilic Erythroblast (PE), Acidophilic Erythroblast (AE), Young Reticulocyte (YR), Mature Reticulocyte (MR), Young Erythrocyte (YE), Mature Erythrocyte (ME), Lymphocyte (LYM), Neutrophil (NEU) and Macrophage (MAC)
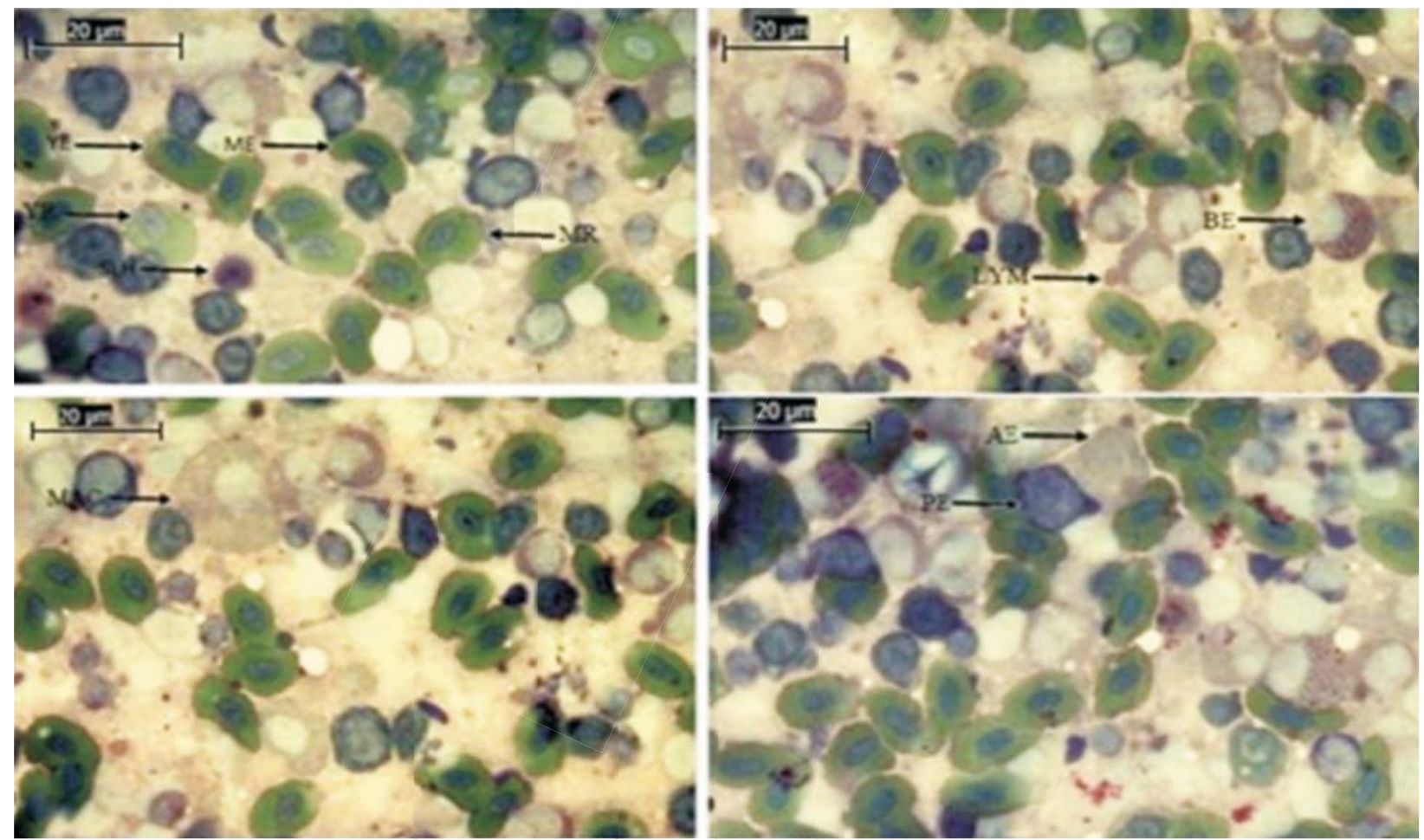

Fig. 2 : An imprint from the head kidney of G. annandalei showing Small Lymphoid Haematoblast (SLH), Basophilic Erythroblast (BE), Polychromatophilic Erythroblast (PE), Acidophilic Erythroblast (AE), Young Reticulocyte (YR), Mature Reticulocyte (MR), Young Erythrocyte (YE), Mature Erythrocyte (ME), Lymphocyte (LYM), Neutrophil (NEU) and Macrophage (MAC) 
Table 1: Characteristics of haematopoietic cells in Garra gotyla gotyla and Garra annandalei ( $n=12$, mean $\pm S E)$

\begin{tabular}{|c|c|c|c|c|c|c|c|c|}
\hline \multirow[t]{3}{*}{ Cell type } & \multicolumn{4}{|c|}{ Area $\left(\mu m^{2}\right)$} & \multicolumn{2}{|l|}{$\mathrm{N}-\mathrm{C}$ ratio } & \multicolumn{2}{|c|}{ Percentage distribution } \\
\hline & \multicolumn{2}{|c|}{ Cell } & \multicolumn{2}{|c|}{ Nucleus } & \multirow{2}{*}{$\begin{array}{l}\text { Garra } \\
\text { gotyla gotyla }\end{array}$} & \multirow{2}{*}{$\begin{array}{l}\text { Garra } \\
\text { annandalei }\end{array}$} & \multirow{2}{*}{$\begin{array}{l}\text { Garra } \\
\text { gotyla gotyla }\end{array}$} & \multirow{2}{*}{$\begin{array}{l}\text { Garra } \\
\text { annandalei }\end{array}$} \\
\hline & $\begin{array}{l}\text { Garra } \\
\text { gotyla gotyla }\end{array}$ & $\begin{array}{l}\text { Garra } \\
\text { annandalei }\end{array}$ & $\begin{array}{l}\text { Garra } \\
\text { gotyla gotyla }\end{array}$ & $\begin{array}{l}\text { Garra } \\
\text { annandalei }\end{array}$ & & & & \\
\hline SLH & $26.14 \pm 2.11$ & $19.66 \pm 0.80$ & $11.84 \pm 2.50$ & $15.50 \pm 0.84$ & $1: 2.21$ & $1: 1.27$ & $2.18 \pm 0.59$ & $7.11 \pm 0.69$ \\
\hline $\mathrm{BE}$ & $75.17 \pm 2.78$ & $55.15 \pm 4.25$ & $49.30 \pm 2.72$ & $34.58 \pm 2.25$ & $1: 1.52$ & $1: 1.59$ & $0.40 \pm 0.17$ & $0.73 \pm 0.26$ \\
\hline PE & $143.17 \pm 3.06$ & $115.53 \pm 3.07$ & $64.59 \pm 0.41$ & $54.35 \pm 2.46$ & $1: 2.22$ & $1: 2.13$ & $6.19 \pm 1.04$ & $7.01 \pm 0.70$ \\
\hline $\mathrm{AE}$ & $117.19 \pm 2.21$ & $65.46 \pm 2.31$ & $51.75 \pm 0.71$ & $43.48 \pm 1.41$ & $1: 2.26$ & $1: 1.51$ & $1.33 \pm 0.29$ & $1.51 \pm 0.25$ \\
\hline YR & $77.80 \pm 1.89$ & $75.50 \pm 2.26$ & $17.09 \pm 1.33$ & $21.69 \pm 0.92$ & $1: 4.55$ & $1: 3.48$ & $14.34 \pm 0.38$ & $14.60 \pm 0.62$ \\
\hline MR & $69.91 \pm 3.32$ & $61.16 \pm 1.02$ & $15.21 \pm 1.15$ & $13.84 \pm 0.46$ & $1: 4.60$ & $1: 4.42$ & $12.32 \pm 1.58$ & $13.85 \pm 0.57$ \\
\hline YE & $54.55 \pm 1.18$ & $51.04 \pm 2.15$ & $14.82 \pm 0.74$ & $11.54 \pm 0.90$ & $1: 3.68$ & $1: 4.42$ & $34.04 \pm 1.94$ & $31.55 \pm 0.45$ \\
\hline ME & $46.53 \pm 1.10$ & $51.80 \pm 1.93$ & $11.98 \pm 0.75$ & $11.93 \pm 0.51$ & $1: 3.88$ & $1: 4.34$ & $21.69 \pm 2.25$ & $16.19 \pm 0.37$ \\
\hline LYM & $27.26 \pm 2.37$ & $20.86 \pm 0.82$ & $6.80 \pm 0.53$ & $10.51 \pm 0.74$ & $1: 4.01$ & $1: 1.98$ & $6.60 \pm 0.69$ & $6.33 \pm 0.35$ \\
\hline NEU & $19.13 \pm 0.93$ & $41.10 \pm 0.86$ & $9.33 \pm 0.28$ & $15.67 \pm 0.86$ & $1: 2.05$ & $1: 2.62$ & $0.41 \pm 0.17$ & $0.63 \pm 0.21$ \\
\hline MAC & $196.46 \pm 2.91$ & $166.53 \pm 2.11$ & $41.19 \pm 1.81$ & $39.19 \pm 1.08$ & $1: 4.77$ & $1: 4.25$ & $0.43 \pm 0.28$ & $0.48 \pm 0.21$ \\
\hline
\end{tabular}

Values are mean of 12 replicates $\pm S E$
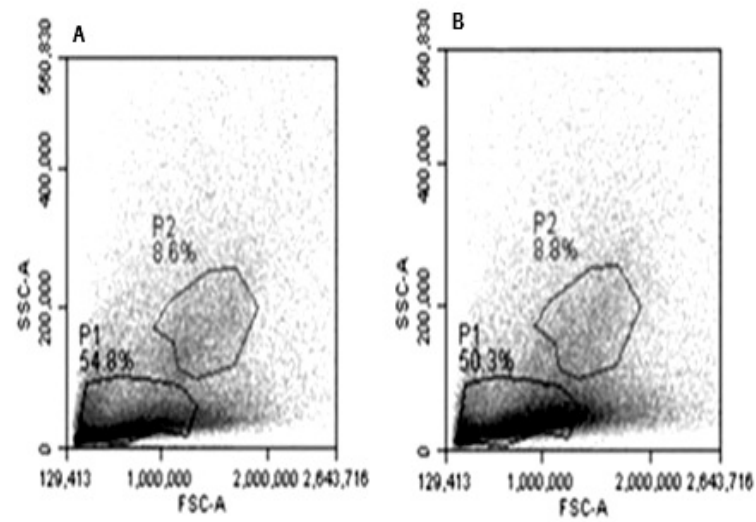

Fig. 3 : FSC-SSC analysis from the head kidney of (A) G. gotyla gotyla and (B) G. annandalei

Eleven types of haematopoietic precursors and mature cells were identified and documented through cytological description and morphometry of erythrocytic and leukocytic cells at different developmental stages (Table 1). The haematopoietic efficiency was also evaluated in both fish to indicate their efficiency to survive in the swift flowing rivers.

The erythrocytic lineage comprised of eight stages namely small lymphoid haematoblast (SLH), basophilic erythroblast $(B E)$, polychromatophilic erythroblast $(\mathrm{PE})$, acidophilic erythroblast (AE), young reticulocyte (YR), mature reticulocyte (MR), young and mature erythrocyte (YE and ME). Lymphocyte (LYM), neutrophil (NEU) and macrophage (MAC) were identified in the lymphocytic lineage (Fig. 1 and Fig. 2).

As suggested by Abdel-Aziz et al. (2010), a combination of quantitative and morphological methods was applied for the classification of fish haematopoietic cells in order to its advancement from the present provisional state. The flow cytometry analysis of the head kidney cells of both the species according to their Forward scatter (size) and Side scatter (granularity) properties revealed two distinct populations corresponding to small agranular (P1-SLH, YR, MR, YE, ME and LYM) and large granular (P2-BE, PE, AE, NEU and MAC) cells (Fig. 3). The percentage distribution of such cells by flow cytometry corroborated with the observation under light microscopy. However, no significant structural variation between the pronephric cell populations of the two fish species was observed.

The teleost head kidney has been considered a haematopoietic organ similar to the bone marrow of higher vertebrates and described as a primitive system (Abdel-Aziz et al., 2010). All the cells in the haematopoietic tissue are similar to other fish species described earlier (Fijan, 2002a, 2002b; AbdelAziz et al., 2010 and Kondera, 2014). Erythroid developmental stages, however, were more numerous than developmental stages of any other lineage (Table 1), similar to the results of Fijan (2002), suggesting high rate of erythropoiesis in both the species to combat high velocity of the hill streams.

The percentage of SLH in both the species was found to be considerably lower than other erythroid developmental stages contradictory to the results obtained by Gangopadhyay and Homechaudhuri (2011) in Clarias batrachus. The percentage of different erythroblast cells were found to be considerably lower in these species compared to the values reported earlier (Fijan, 2002b; Gangopadhyay and Homechaudhuri, 2011; Kondera et al., 2012; Kondera, 2014). Erythrocytes were more numerous than erythroblasts in this tissue, unlike the previous findings. Erythropoietic efficiency in the recent study was found to be much higher than that of $O$. niloticus as reported by Homechaudhuri and Jha (2001). It indicated limited storage of erythroid cells and faster 


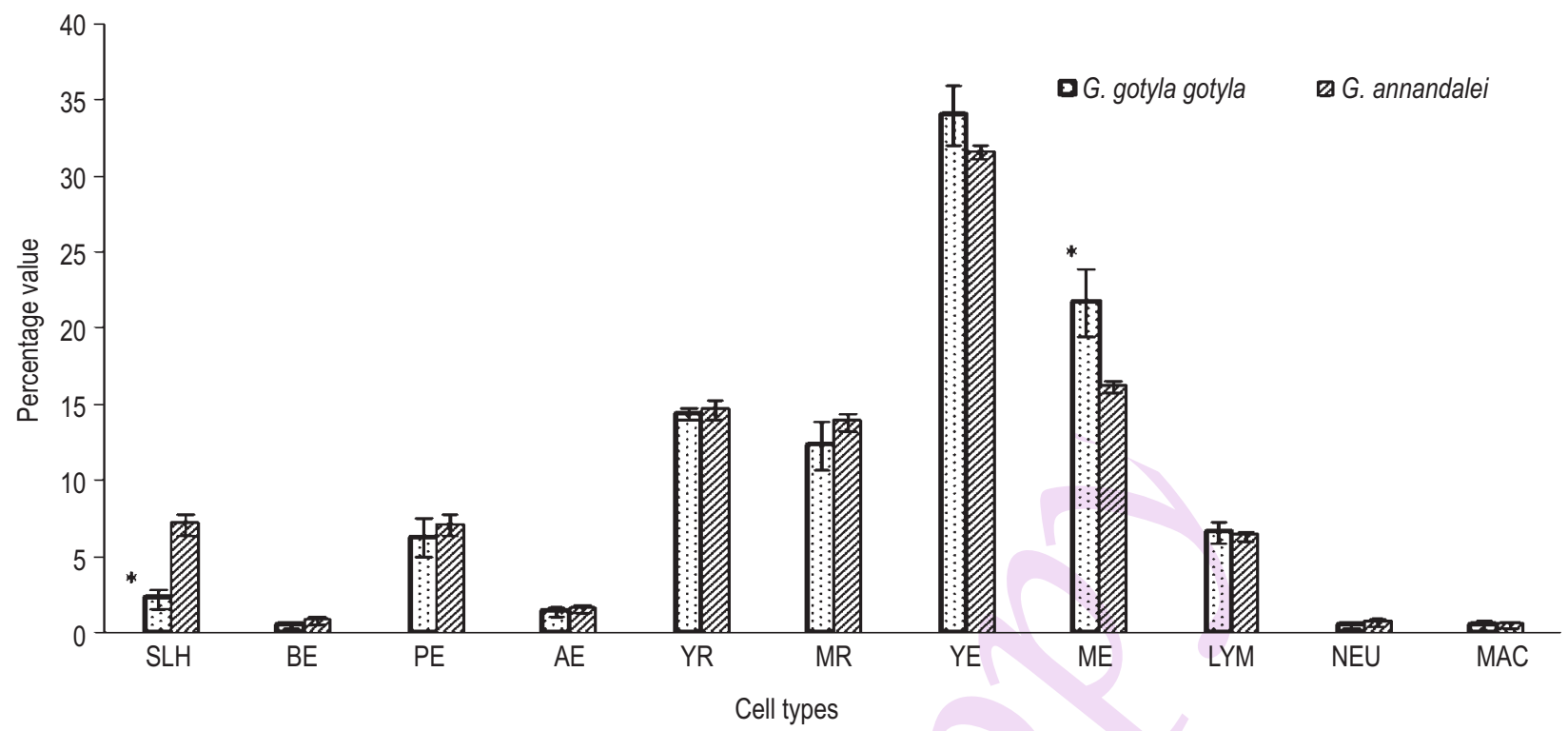

Fig. 4 : Comparative study on percentage distribution of haematopoietic cells in G. gotyla gotyla and G. annandalei; *significant $(P<0.05)$
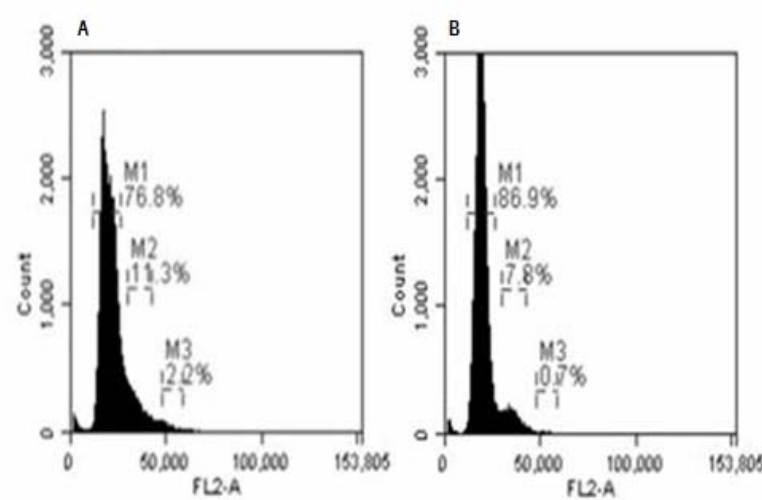

Fig. 5 : Flow cytometric study of head kidney in G. gotyla gotyla (A) and $G$. annandalei (B) showing phases of cell cycle

turnover rate of erythrocyte developmental stages into mature ones to maintain the high oxygen demand in fast swimmers.

The percentage of lymphoid cells in the head kidney of same fish species may vary (Kondera, 2011). In the present study, the percentage of these cells were similar to the values reported by Wlasow and Dabrowska (1989) in Cyprinus carpio, but much lower than that in common carp and channel catfish (Fijan, 2002b; Kondera, 2011). Lymphocyte was the most frequent cell of lymphoid lineage in the species under study, similar to the findings of Fijan (2002b), Liu et al. (2004) and Kondera (2011). The leukopoiectic efficiency data also reflected lesser requirement of lymphoid cells than erythroid cells in both the species.

Moreover, quantitative variation among erythroid lineage cells between $\mathrm{G}$. gotyla gotyla and $\mathrm{G}$. annandalei were distinct.
The small lymphoid haematoblast, a developing cell type, was found to be significantly less in $G$. gotyla gotyla compared to $G$. annandalei. In contrast, the mature erythrocyte cells were significantly numerous in G. gotyla gotyla than G. annandalei (Fig 4). Significantly higher erythropoietic efficiency in G. gotyla gotyla was also suggestive of the higher turn-over rate of the storage form (SLH) into mature erythrocytes in this species compared to G. annandalei. This finding was further supported by cell cycle analysis for head kidney tissue following flow cytometry. The results showed $76.8 \%$ cells in the G0-G1 (undivided and first growth) phase (M1), $11.3 \%$ cells in the $S$ (synthetic) phase (M2) and $2.2 \%$ cells in the G2-M (second growth and mitotic) phase (M3) of the cell cycle in G. gotyla gotyla, where as $86.9 \%$ cells in the $\mathrm{G} 0-\mathrm{G} 1$ phase (M1), $7.8 \%$ cells in the $\mathrm{S}$ phase (M2) and $0.7 \%$ cells in G2-M phase (M3) in G. annandalei (Fig 5). However, a higher value of $S$ phase cells might indicate higher rate of cell division which imparts greater efficiency to meet higher oxygen demand of $G$. gotyla gotyla compared to $G$. annandalei.

To find the correlation between haematopoiesis and habitat condition, frequency of two species at three sites of River Murti (MR-I, MR-II and MR-III) were assessed. The results showed significantly high frequency of $G$. gotyla gotyla in the upper reaches (MR-I and MR-II) with high velocity of water and oxygen demand. Conversely, significantly high frequency of $G$. annandalei was obtained in the lower reach (MR-III) of the river. The findings explained frequency distribution of the two species in the river Murti in relation to the variations in oxygen availability. Such pattern of abundance was also correlated with the variation and efficiency in haematopoietic activity for their survival in different habitat conditions. 
In conclusion, the quantitative differences in the cellular composition of the head kidney in different species under study have been reflected indicating influence of environmental factors like physico-chemical water parameters and stressors in addition to biological changes due to age, sex and reproduction. It indicates adaptive significance of haematopoietic profile to understand the survival strategy of fish in the hill stream environments for their conservation.

\section{Acknowledgments}

The authors are thankful to the University Grants Commission, New Delhi for financial assistance, the Head of the Department of Zoology, University of Calcutta for providing infrastructural facilities and Dr. Sanjaya Mallick for technical assistance.

\section{References}

Abdel-Aziz, E.S.H., S.B.S. Abdu, T.E.S. Ali and H.F. Fouad: Haemopoiesis in the head kidney of tilapia, Oreochromis niloticus (Teleostei: Cichlidae): A morphological (optical and ultrastructural) study. Fish Physiol. Biochem., 36, 323-336 (2010).

Abell, R., M.L. Thieme, C. Revenga, M. Bryer, M. Kottelat, N. Bogutskaya, B. Coad, N. Mandrak, S.C Balderas, W. Bussing, M.L.J. Stiassny, P. Skelton, G.R. Allen, P. Unmack, A. Naseka, R. Ng, N. Sindorf, J. Robertson, E. Armijio, J.V. Higgins, T.J. Heibel, E. Wikramanayake, D. Olson, H.L. Lopez, R.E. Reis, J.G. Lundberg, M.H.S. Perez and P. Petry: Freshwater ecoregions of the World: A new map of biogeographic units for freshwater biodiversity conservation. Bioscience, 58, 403-414 (2008).

Acharjee, M.L. and S. Barat: Spatio-temporal dynamics of physicochemical factors of river Relli in Darjeeling Himalaya, West Bengal, India. NBU J. Anim. Sci., 5, 24-33 (2011).

Acharjee, M.L. and S. Barat: Ichthyofaunal diversity of Teesta River in Darjeeling Himalaya of West Bengal, India. Asian J. Exp. Bio. Sci., 4, 112-122 (2013).

Acharjee, M.L. and S. Barat: Seasonal dynamics of ichthyodiversity in a hill stream of the Darjeeling Himalaya, West Bengal, India. J. Threatened Taxa, 6, 6635-6648 (2014).

Bahuguna, S.N. and A.K. Badoni: Qualitative and quantitative productivity of fish food from three important tributaries of river Alaknanda. Himlayan J. Environ. Zool., 16, 215-222 (2002).

Chakrabarty, M. and S. Homechaudhuri: Fish guild structure along a longitudinally-determined ecological zonation of Teesta, an eastern Himalayan river in West Bengal, India. Arxius de Miscel/lània Zoològica, 11, 196-213 (2013).

Chen, A.T. and L.I. Zon: Zebrafish blood stem cells. J. Cell Biochem., 108, 35-42 (2009).

Davidson, A.J. and L.I. Zon: The 'definitive' (and 'primitive') guide to zebrafish hematopoiesis. Oncogene, 43, 7233-7246 (2004).
Day, F.: The fauna of British India: Fishes.Taylor and Francis, London. (1889).

Fijan, N.: Morphogenesis of blood cell lineages in channel catfish. J. Fish Biol., 60, 999-1014 (2002a).

Fijan, N.: Composition of main haematopoietic compartments in normal and bled channel catfish. J. Fish Biol., 60, 1142-1154 (2002b).

Forteza Bover, G.:Atlas of Blood Cytology, Grune and Stratton, New York and London (1964).

Gangopadhyay, K. and S. Homechaudhuri: Descriptive characteristics of haemopoietic cell lineages in a facultative air breathing fish Clarias batrachus (L.). Turk. J. Zool., 35, 737-746 (2011).

Gupta, A.K. and A. Kumar: Histopathological lesions in the selected tissues of Cirrhinus mrigala (Ham.) fingerlings exposed to a sublethal concentration of mercury. J. Env. Biol., 27, 235-239 (2006).

Homechaudhuri, S. and A. Jha: A technique to evaluate the erythropoietic efficiency in fish. Asian Fish Sci., 14, 453-455 (2001).

Kondera, E.: Haematopoiesis in the head kidney of common carp (Cyprinus carpio L.): A morphological study. Fish Physiol. Biochem., 37, 355-362 (2011).

Kondera, E., A. Dmowska, M. Rosa and M. Witeska: The effect of bleeding on peripheral blood and head kidney hematopoietic tissue in common carp (Cyprinus carpio). Turk. J. Vet. Anim. Sci. 36, 169-175(2012).

Kondera, E.: Cell composition of the head kidney of European chub (Squalius cephalus L.). Arch. Pol. Fish., 22, 271-280(2014).

Kulkeaw, K. and D. Sugiyama: Zebra fish erythropoiesis and the utility of fish as models of anemia. Stem Cell Res. Thera., 3, 55-65 (2012).

Liu, Y., S. Zhang, G. Jiang, D. Yang, J. Lian and Y. Yang: The development of the lymphoid organs of flounder, Paralichthysolivaceus, from hatching to 13 months. Fish Shellfish Immunol., $16,621-632$ (2004).

Loken, M.R.:Immunofluorescent technique in flowcytometry and sorting. $2^{\text {nd }}$ Edn., Willey (1990).

Mahajan, C.L. and J.M.S. Dheer: Autoradiography and differential haemoglobin staining as aids to the study of fish haematology. Experientia , 35, 834-835(1979).

Mahajan, C.L. and J.M.S. Dheer: Origin and development of neutrophils in an air breathing fish Channa punctatus Bloch. Acta Zool., 61, 251-254(1980).

Santos, A.A., R.C. Gutierre, M.M. Antoniazzi, M.J.T. Ranzani-Paiva, M.R.R. Silva, C.T.F. Oshima and M.I. Egami: Morphocyto chemical, immunohisto chemical and ultra structural characterization of the head kidney of fat snook Centropomus parallel. J. Fish Biol., 79, 1685-1707 (2011).

Talwar, P.K. and A.G. Jhingran: Inland Fishes of India and Adjacent Countries. Vol. 1, 2, Oxford and IBH Publishing Co. Pvt. Ltd., New Delhi (1991).

Wlasow, T. and H. Dabrowska: Cellular changes in the blood and haemopoietic tissues of common carp exposed to sublethal concentration of ammonia. Aquat. Liv. Resour., 2, 169-174 (1989). 